Jurnal Pemikiran \& Penelitian Psikologi

\title{
PSIKOLOGIA
}

p-ISSN: $185-0327$

e-ISSN: $2549-2136$

www.jurnal.usu.ac.id/psikologia

\section{PENGARUH KOMUNIKASI DARI MULUT KE MULUT DAN TIPE KEPRIBADIAN TERHADAP INTENSI PERPINDAHAN MEREK KOSMETIK}

THE EFFECT OF COMMUNICATIONS FROM MOUTH TO MOUTH AND THE PERSONALITY TYPE TOWARD TRANSFER INTENTION OF COSMETIC BRAND

\section{Yuni Asmidar, Zulkarnain, Eka Danta Jaya Ginting}

Psikologia: Jurnal Pemikiran \& Penelitian Psikologi

Tahun 2017, Vol. 12, No. 1, hal.30-42

Artikel ini dapat diakses dan diunduh pada:

www.jurnal.usu.ac.id/psikologia

\section{Dipublikasikan oleh:}

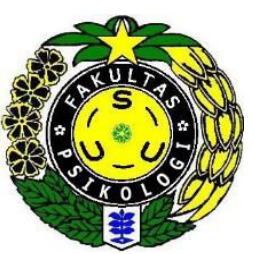

Fakultas Psikologi

Universitas Sumatera Utara

Jl. Dr. Mansyur No. 7 Medan. Telp/fax: 061-8220122

Email: psikologia@usu.ac.id 


\title{
PENGARUH KOMUNIKASI DARI MULUT KE MULUT DAN TIPE KEPRIBADIAN TERHADAP INTENSI PERPINDAHAN MEREK KOSMETIK
}

\author{
Yuni Asmidar, Zulkarnain, Eka Danta Jaya Ginting \\ Universitas Sumatera Utara
}

\begin{abstract}
ABSTRAK
Konsumen cenderung untuk beralih merek dibanding loyal terhadap suatu merek. Faktor paling kuat dalam mempengaruhi intensi berpindah merek pada konsumen adalah komunikasi dari mulut ke mulut. Disisi lain, tipe kepribadian juga turut berperan terhadap intensi berpindah pada konsumen. Penelitian ini bertujuan untuk menganalisis pengaruh komunikasi dari mulut ke mulut dan tipe kepribadian terhadap intensi perpindahan merek kosmetik X ke merek kosmetik lain. Subjek dalam penelitian ini adalah 263 wanita pengguna kosmetik $X$ dengan metode pengambilan sampel yaitu purposive sampling. Penelitian ini menggunakan tiga skala yaitu skala komunikasi dari mulut ke mulut, skala tipe kepribadian, dan skala intensi perpindahan merek. Data yang diperoleh kemudian dianalisis dengan menggunakan anakova. Hasil penelitian menunjukkan terdapat pengaruh yang signifikan antara komunikasi dari mulut ke mulut dan tipe kepribadian terhadap intensi perpindahan merek. Implikasi dari penelitian ini adalah perusahaan kosmetik dapat memanfaatkan komunikasi dari mulut ke mulut yang positif mengenai produknya sebagai strategi dalam menarik konsumen baru.
\end{abstract}

Kata kunci: intensi perpindahan merek, komunikasi dari mulut ke mulut, tipe kepribadian, kosmetik, wanita

\section{THE EFFECT OF COMMUNICATIONS FROM MOUTH TO MOUTH AND THE PERSONALITY TYPE TOWARD TRANSFER INTENTION OF COSMETIC BRAND}

\begin{abstract}
S
Consumers tend to switch brands rather than loyal to a brand. The most powerful factor in affect brand switching intentions to consumers is commmunications from mouth to mouth. In the other side, personality types also contribute to switching intentions to consumers. This research was aimed to analyze the effect of communications from mouth to mouth and personality type to the intention of switching cosmetic brand $\mathrm{X}$ to the other cosmetic brands. Subjects in this research were 263 women cosmetic $\mathrm{X}$ users with purposive sampling as sampling method. This research used three scales of communication from mouth to mouth scale, personality type scale, and intentions of brand switching scale. Data obtained then analyzed by using anakova. The results show that there is a significant effect between communication from mouth to mouth and personality type to the intention of switching brand. The implication of this research is that cosmetic companies can take advantage of positive communication from mouth to mouth about their products as a strategy to attract new customers.
\end{abstract}

Keyword: Intention of switching brand, communication from mouth to mouth, personality type, cosmetics, women

*Korespondensi mengenai penelitian ini dapat dilayangkan kepada: 09.062ya@gmail.com
Rekomendasi mensitasi:

Asmidar, Y., Zulkarnain, Ginting, E.D.J. (2017).

Pengaruh Komunikasi dari Mulut ke Mulut dan Tipe Kepribadian terhadap Intensi Perpindahan Merek Kosmetik. Psikologia :Jurnal Pemikiran dan Penelitian Psikologi, 12(1), 30-42 


\section{PENDAHULUAN}

Salah satu kebutuhan yang bisa dibilang pokok bagi kaum wanita adalah kosmetik (Nandifa, 2016). Tilaar (1999) menyatakan bahwa kosmetika awalnya hanya sekedar alat bantu, tapi akibat ketergantungan perempuan modern yang begitu besar, kosmetika menjadi segala-galanya. Hal ini sesuai dengan hasil jajak pendapat kompas yang diselenggarakan pada 18-20 Mei 2016 dengan responden sebanyak 655 dari 12 kota besar menemukan bahwa sebanyak $73.3 \%$ responden mengatakan bahwa menggunakan kosmetik ketika bepergian itu penting dan sisanya mengatakan tidak penting. Selain itu, hampir seluruh responden (92.7\%) sepakat menyatakan bahwa perempuan saat ini mengenakan kosmetik di usia yang lebih muda dibandingkan generasi yang lahir sebelum 1990 (Nugraheni, 2016).

Kondisi tersebut dimanfaatkan betul oleh produsen kosmetik. Hal ini terkait dengan jumlah penduduk Indonesia yang diproyeksi akan menembus angka 271 juta pada tahun 2020. Dengan angka pertumbuhan yang cukup besar tersebut, maka Indonesia merupakan pasar yang sangat potensial bagi perusahaan kosmetik (Pratiwi, 2017).

Salah satu merek kosmetik favorit wanita di Indonesia adalah $\mathrm{X}$ (Femina, 2016). Hasil survei Frontier Consulting Group menunjukkan bahwa beberapa produk merek X mampu menduduki posisi top brand pada tahun 2016. Meskipun X terbilang baru dibanding kosmetik lokal lainnya yang sudah puluhan tahun hidup di Nusantara, namun $\mathrm{X}$ berhasil membuat gebrakan sebagai pionir kosmetik halal pada tahun 1995 dan menjawab serta memenuhi kebutuhan wanita muslim dalam dunia kecantikan (Femina, 2016).

Jika $\mathrm{X}$ berhasil memikat konsumen dengan label halalnya, maka saat ini beberapa produsen kosmetik asing atau multinasional juga sudah memiliki pabrik kosmetik bersertifikat halal di Indonesia. Pasar kosmetik memang terbilang besar akan tetapi tantangannya juga besar. Tantangan tersebut diantaranya adalah bagaimana bersaing memperebutkan konsumen (Pratiwi, 2017).

Destarania (2012) menyatakan bahwa hasil analisis Worldpanel Indonesia menemukan bahwa loyalitas konsumen Indonesia tergolong rendah. Peluang untuk beralih merek rata-rata cenderung lebih tinggi daripada persentase untuk loyal terhadap satu merek tertentu. Sekarang ini konsumen jarang yang ketergantungan terhadap satu merek tertentu, mereka cenderung untuk beralih merek.

Perpindahan merek merupakan keputusan konsumen untuk membeli merek produk yang berbeda dari yang sebelumnya atau biasanya dibeli ( Imber, 2000). Perilaku seseorang untuk beralih merek juga dilihat dari intensi mereka. Intensi adalah niat sadar untuk menjalankan suatu tindakan (Ajzen dan Fishbein, 1975).

Ada beberapa faktor yang dapat mempengaruhi intensi seseorang untuk melakukan perpindahan yaitu citra merek (Radamuri, Farida, \& Dewi, 2013), Iklan (Radamuri et al., 2013), kebutuhan mencari variasi (Khasanah \& Kuswati, 2013) (Nuraeni, 2014), harga (Ananda, 2015), 
tingkat keterlibatan (Nuraeni, 2014) atribut produk (Emelia, 2013), kualitas produk (Khasanah \& Kuswati., 2013) dan komunikasi dari mulut ke mulut (Radamuri et al., 2013).

Komunikasi dari mulut ke mulut mengacu kepada pertukaran komentar, pemikiran, atau ide-ide di antara dua konsumen atau lebih, yang tak satupun merupakan sumber pemasaran (Mowen \& Minor, 2002). Radamuri et al. (2013) menemukan bahwa variabel komunikasi dari mulut ke mulut berpengaruh positif sebesar $73.1 \%$ terhadap keputusan perpindahan merek pengguna handphone non blackberry ke handphone blackberry. Bahkan, Peter dan Olson (2000) menemukan bahwa pemasar berharap dapat mendorong terjadinya promosi berbentuk komunikasi dari mulut ke mulut, karena metode ini membantu penyebaran kesadaran produk hingga menjangkau konsumen yang tidak bisa dijangkau oleh perusahaan melalui kontak promosi secara langsung. Suryani (2008) juga menyatakan bahwa bagi masyarakat indonesia komunikasi dari mulut ke mulut mempunyai pengaruh yang kuat. Masyarakat cenderung lebih suka mendengarkan daripada membaca, dalam mencari informasi pun lebih banyak bertanya kepada orang lain yang dipercaya.

Mowen dan minor (2002) menyatakan bahwa sebuah survei yang dilakukan dengan bertanya kepada konsumen tentang faktorfaktor yang mempengaruhi pembelian mereka atas 60 produk yang berbeda, ternyata acuan dari orang lain berpengaruh terhadap pembelian lebih besar daripada iklan. Studi lainnya menemukan bahwa komunikasi dari mulut kemulut dua kali lebih efektif dari iklan radio, empat kali lebih efektif dari personal selling dan tujuh kali lebih efektif dari surat kabar dan majalah.

Faktor lain yang mempengaruhi intensi perpindahan merek adalah kepribadian individu. Ramshita dan Manikandan (2013) menemukan adanya pengaruh kepribadian terhadap intensi perpindahan merek, dimana individu dengan kepribadian activation cenderung paling rendah melakukan perpindahan merek. Pengaruh kepribadian terhadap keputusan membeli juga dikemukakan oleh Boyd (2000), yang menemukan bahwa meskipun dua orang konsumen memiliki keterlibatan yang sama terhadap suatu produk, mereka sering membeli produk yang berbeda karena alasan yang berbeda. Informasi yang mereka kumpulkan, cara mereka memproses dan menjabarkannya serta evaluasi mereka terhadap merek-merek alternatif semuanya dipengaruhi oleh karakteristik psikologis dan pribadi. Hal ini juga diperkuat oleh hasil penelitian Darmawati, Surbekti, Murni, dan Sumarsono (2007) yang menunjukkan bahwa variabel kepribadian mempunyai pengaruh paling besar terhadap keputusan pembelian produk Shar'e. Oleh karena itu, hasil penelitian ini menyarankan pihak perusahaan untuk memperhatikan faktor kepribadian dalam pengembangan dan pemasaran produk.

Kepribadian dapat didefinisikan sebagai suatu bentuk dari sifat-sifat yang ada pada diri individu yang sangat menentukan perilakunya. Kepribadian konsumen akan mempengaruhi persepsi dan pengambilan keputusan dalam membeli (Mangkunegara, 2009). Kepribadian manusia dapat 
digolongkan menjadi dua tipe yaitu tipe ekstravers dan tipe introvers. Seorang yang ekstravers terutama dipengaruhi oleh dunia obyektif, yaitu dunia di luar dirinya. Orientasinya terutama tertuju keluar. Pikiran, perasaan, serta tindakannya terutama ditentukan oleh lingkungannya, baik lingkungan sosial maupun lingkungan non-sosial. dia bersikap positif terhadap masyarakatnya: hatinya terbuka, mudah bergaul, hubungan dengan orang lain lancar (Suryabrata, 2008).

Mantasari, Rahmawati, dan Silviandari (2013) serta Venny (2010) menemukan bahwa perpindahan merek dapat terjadi karena adanya pengaruh dari reference group seperti teman atau keluarga berupa dorongan, tekanan, kemudahan berkomunikasi, kualitas merek, status sosial dan nilai prestige merek. Olsen, Tudoran, Honkanen, dan Verplanken (2016) juga menemukan bahwa ada hubungan yang signifikan antara extraversion dengan kebutuhan mencari variasi. Dimana hasil penelitian Nuraeni (2014) menyatakan bahwa perilaku perpindahan merek dapat muncul karena adanya kebutuhan mencari variasi.

Seorang yang introvers terutama dipengaruhi oleh dunia subyektif, yaitu dunia di dalam dirinya sendiri. Orientasinya terutama tertuju ke dalam: pikiran, perasaan, serta tindakan-tindakannya terutama ditentukan oleh faktor-faktor subyektif. Penyesuaiannya dengan dunia luar kurang baik; jiwanya tertutup, sukar bergaul, sukar hubungan dengan orang lain, kurang dapat menarik hati orang lain. Penyesuaian dengan batinnya sendiri baik (Suryabrata, 2008). Undari (2016) menemukan bahwa siswa yang memiliki tipe kepribadian introvert, mereka tidak mudah terpengaruh terhadap bujuk rayuan iklan saat akan membeli barang atau memiliki kontrol diri yang baik. Karena tipe kepribadian introvert cenderung pendiam dan tidak terlalu memperhatikan orang lain. Hal ini membuat orang introvert tidak begitu memperhatikan barang yang sedang tren di kalangan remaja atau mengikuti gaya hidup teman sebagai bentuk konformitas terhadap teman sebaya.

Berdasarkan uraian tersebut, maka permasalahan dalam penelitian ini adalah apakah ada pengaruh komunikasi dari mulut ke mulut dan tipe kepribadian ekstrovert dan introvert terhadap intensi perpindahan merek kosmetik X ke merek kosmetik lain?

\section{KERANGKA TEORITIS}

\section{Intensi Perpindahan Merek}

Intensi yaitu keinginan untuk melakukan sesuatu, mempunyai tujuan (Sudarsono,1993). Ajzen dan Fishbein (1975) mendefinisikan intensi sebagai probabilitas atau peluang seseorang bahwa ia akan melakukan suatu perilaku. Perpindahan merek merupakan pola pembelian yang ditandai dengan perubahan dari satu merek ke merek yang lain (Peter \& Olson, 2010). Oleh karena itu, intensi perpindahan merek adalah keinginan seseorang untuk membeli merek yang berbeda dari sebelumnya atau biasanya dibeli namun dengan produk yang tetap sama serta dapat diwujudkan pada waktu dan kesempatan yang tepat disertai upaya untuk melakukannya.

Intensi perpindahan merek terdiri atas aspek-aspek intensi yang dikemukakan oleh 
Ajzen dan Fishbein (1975) yang dikaitkan dengan konteks perpindahan merek yaitu perilaku (behavior) merupakan perilaku spesifik yang nantinya akan diwujudkan, sasaran (target) yaitu objek yang menjadi sasaran perilaku, situasi (situation) yaitu situasi yang mendukung untuk dilakukannya suatu perilaku (bagaimana dan dimana perilaku itu akan diwujudkan), dan waktu (time), yaitu waktu terjadinya perilaku yang meliputi waktu tertentu, dalam satu periode atau tidak terbatas dalam satu periode, misalnya waktu yang spesifik (hari tertentu, tanggal tertentu, jam tertentu), periode tertentu (bulan tertentu), dan waktu yang tidak terbatas (waktu yang akan datang).

\section{Komunikasi dari Mulut ke Mulut}

Komunikasi dari mulut ke mulut mengacu pada pertukaran komentar, pemikiran, atau ide-ide di antara dua konsumen atau lebih, yang tak satupun merupakan sumber pemasaran (Mowen \& Minor, 2002). . Hal ini sejalan dengan Hoyer dan Maclnnis (2016) yang menyatakan bahwa komunikasi dari mulut ke mulut yaitu pengaruh yang disampaikan secara lisan dari satu orang ke orang lain atau sekelompok orang.

Harrison-Walker (2001) menyatakan bahwa komunikasi dari mulut ke mulut terdiri dari beberapa aspek yaitu Antusiasme (Enthusiasm) yang meliputi frekuensi (seberapa sering individu terlibat dalam komunikasi dari mulut kemulut) dan jumlah kontak (berapa banyak orang yang mengajaknya terlibat dalam komunikasi dari mulut ke mulut), detail (Detail) yaitu seberapa banyak yang dikatakan (jumlah informasi yang diberikan si pengirim kepada si penerima) dan terakhir pujian (Praise) yaitu favorablesnees atau komunikasi dari mulut kemulut yang bersifat positif (pengalaman yang menyenangkan, merekomendasikan kepada orang lain, dan lain sebagainya.

\section{Tipe Kepribadian}

Jung menyatakan bahwa kepribadian manusia dapat digolongkan menjadi dua tipe yaitu (Suryabrata, 2008) : tipe ekstrovert dan tipe introvert. Orang yang ekstravert terutama dipengaruhi oleh dunia obyektif, yaitu dunia di luar dirinya. Orientasinya terutama tertuju keluar. Pikiran, perasaan, serta tindakannya terutama ditentukan oleh lingkungannya, baik lingkungan sosial maupun lingkungan non-sosial. Dia bersikap positif terhadap masyarakatnya: hatinya terbuka, mudah bergaul, hubungan dengan orang lain lancar. Sedangkan orang yang introvert terutama dipengaruhi oleh dunia subyektif, yaitu dunia di dalam dirinya sendiri. Orientasinya terutama tertuju ke dalam: pikiran, perasaan, serta tindakantindakannya terutama ditentukan oleh faktor-faktor subyektif. Penyesuaiannya dengan dunia luar kurang baik; jiwanya tertutup, sukar bergaul, sukar hubungan dengan orang lain, kurang dapat menarik hati orang lain. Penyesuaian dengan

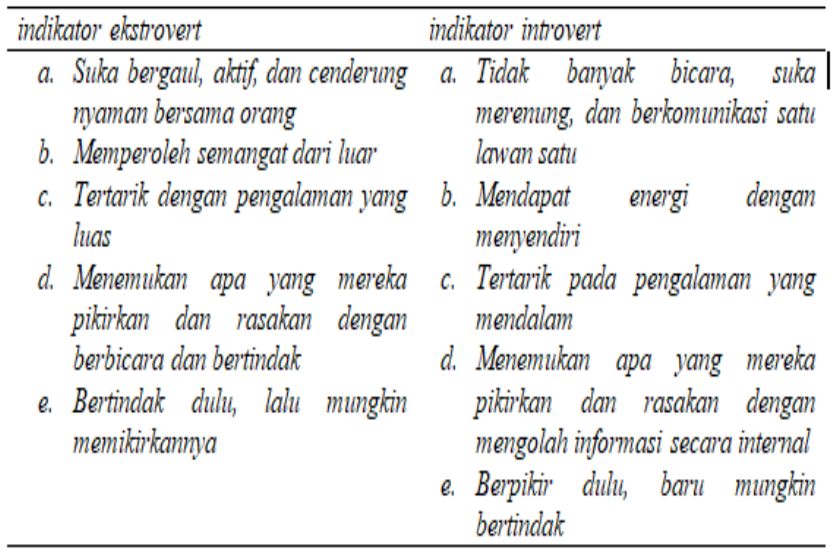


batinnya sendiri baik.

Berdasarkan tipologi Jung, indikator ekstrovert dan introvert dibagi menjadi beberapa bagian yaitu

\section{HIPOTESA PENELITIAN}

Hipotesis yang akan diuji dalam penelitian ini antara lain:

1. Terdapat pengaruh komunikasi dari mulut ke mulut terhadap intensi perpindahan merek

2. Terdapat pengaruh tipe kepribadian terhadap intensi perpindahan merek

3. Terdapat pengaruh komunikasi dari mulut ke mulut dan tipe kepribadian terhadap intensi perpindahan merek.

\section{METODE PENELITIAN}

\section{Identifikasi Variabel Penelitian}

1. Variabel tergantung : intensi perpindahan merek $(\mathrm{Y})$

2. Variabel bebas komunikasi dari mulut kemulut (X1) dan tipe kepribadian (X2)

\section{Definisi Operasional dan Pengukuran Variabel}

Intensi perpindahan merek adalah keinginan seseorang untuk membeli merek yang berbeda dari sebelumnya atau biasanya dibeli namun dengan produk yang tetap sama yang dapat diwujudkan pada waktu dan kesempatan yang tepat disertai upaya untuk melakukannya. Intensi perpindahan merek akan diukur dengan menggunakan skala intensi perpindahan merek yang disusun berdasarkan aspek yang dikemukakan oleh Ajzen dan Fishbein (1975) yaitu perilaku, sasaran, situasi dan waktu.

Komunikasi dari mulut ke mulut adalah kegiatan komunikasi yang terjadi ketika konsumen berbagi informasi kepada konsumen lainnya mengenai suatu produk namun tak satupun dari mereka merupakan sumber pemasaran. Komunikasi dari mulut ke mulut akan diukur menggunakan skala komunikasi dari mulut ke mulut yang disusun berdasarkan aspek-aspek yang dikemukakan oleh Harrison-Walker (2001) yaitu antusiasme, detail, dan pujian.

Tipe kepribadian ekstrovert adalah tipe kepribadian yang dipengaruhi oleh dunia yang ada di luar dirinya serta orientasinya tertuju keluar, seperti suka bergaul, tanggap terhadap lingkungan, memiliki mood yang berubah-ubah, impulsif dalam bertindak, suka kegiatan, suka perubahan, dan beradaptasi dengan mudah.

Tipe kepribadian introvert adalah tipe kepribadian yang dipengaruhi oleh dunia yang ada didalam dirinya sendiri serta orientasinya tertuju keadalam, seperti suka melamun, menghindari kontak sosial, tenang, tidak terlalu emosional, berpikir dahulu sebelum bertindak, suka termenung, tidak menyukai perubahan dan tidak mudah beradaptasi. Tipe kepribadian ekstrovert dan introvert akan diukur menggunakan indikator-indikator yang berasal dari tipologi Jung (Baron \& Wagele, 1994). 


\section{Sampel dan Metode Pengambilan Sampel}

Berdasarkan tabel sampel Krejcie dan Morgan (dalam Sekaran, 2006), jika jumlah populasi tak terhingga maka jumlah sampel yang diperlukan adalah 384 orang. Oleh karena itu peneliti menggunakan sampel sebanyak 384 orang. Adapun karakteristik populasi yang akan diteliti adalah wanita pengguna produk kosmetik merek $\mathrm{X}$.

\section{Metode Pengumpulan Data}

Metode pengumpulan data yang akan digunakan dalam penelitian ini adalah metode skala dengan menggunakan model likert. Adapun skala-skala yang digunakan pada penelitian ini yaitu:skala intensi perpindahan merek, komunikasi dari mulut ke mulut dan tipe kepribadian.

\section{ANALISIS DATA DAN HASIL PENELITIAN}

\section{Uji Asumsi}

\section{Uji Normalitas}

Uji normalitas dimaksudkan untuk memperlihatkan bahwa sampel diambil dari populasi yang berdistribusi normal. Uji normalitas sebaran menggunakan uji onesample Kolmogorov-Smirnov.

Hasil Uji one-sample KolmogorovSmirnov

\begin{tabular}{lcc}
\hline Variabel & $P$ & Keterangam \\
\hline Intensi Perpindahan Merek & .188 & Normal \\
Komunikasi dari mulut ke mulut & .150 & Normal \\
\hline
\end{tabular}

\section{Uji Linieritas}

Uji linieritas bertujuan untuk mengetahui apakah dua variabel secara signifikan mempunyai hubungan yang linier atau tidak. Uji linieritas menggunakan uji test for linearity.

Hasil Uji Test For Linearity

\begin{tabular}{|c|c|c|}
\hline Model & $\mathrm{p}$ & Keterangan \\
\hline komunikasi dari & & \\
\hline mulut & & Hubungan \\
\hline $\begin{array}{l}\text { mulut*Intensi } \\
\text { perpindahan merek }\end{array}$ & 000 & linier \\
\hline
\end{tabular}

\section{Uji Homogenitas}

Uji homogenitas dimaksudkan untuk memperlihatkan bahwa kelompok atau lebih data sampel berasal dari populasi yang memiliki variansi yang sama. Pengukuran homogenitas dilakukan melalui levene's test.

Hasil Uji Levene's Test

\begin{tabular}{ccccc}
\hline$F$ & $d f 1$ & $d f 2$ & $p$ & Keterangan \\
\hline 2.737 & 1 & 261 & .099 & Homogen \\
\hline
\end{tabular}

\section{Uji Homogeneity of Regression Sloves}

Uji homogeneity of regression sloves dimaksudkan untuk memperlihatkan bahwa tidak ada interaksi antara kovariat dan variabel independen.

Hasil Uji Homogeneity of Regression Sloves

\begin{tabular}{lllllll}
\hline Variabel & $\begin{array}{l}\text { Type III Sum } \\
\text { of Squares }\end{array}$ & $d f$ & MS & $F$ & $P$ & Ket \\
\hline $\begin{array}{l}\text { tipekepri* } \\
\text { wom }\end{array}$ & .585 & 1 & .585 & .007 & .932 & $\begin{array}{l}\text { Tidak } \\
\text { ada } \\
\text { interaksi }\end{array}$ \\
\hline
\end{tabular}


Hasil Uji Hipotesa Penelitian

Pengaruh Komunikasi dari Mulut ke Mulut terhadap Intensi Perpindahan Merek

Hipotesis pertama pada penelitian ini adalah ada pengaruh komunikasi dari mulut ke mulut terhadap intensi perpindahan merek. Dari hasil uji anakova diperoleh hasil seperti di bawah ini:

Hasil Uji Anakova Komunikasi dari Mulut Kemulut dan Intensi Perpindahan

\begin{tabular}{|c|c|c|c|c|c|}
\hline Itrival & $\begin{array}{l}\text { Tipe III Siun } \\
\text { of Sylures }\end{array}$ & if MS & $F$ & $p$ & $\begin{array}{l}\text { Partial Etan } \\
\text { Sglurered }\end{array}$ \\
\hline $\begin{array}{l}\text { Komminikasi dari } \\
\text { mullut kemulutht }\end{array}$ & 9308.143 & & & .000 & .307 \\
\hline
\end{tabular}

Merek

Berdasarkan tabel terlihat bahwa angka signifikansi untuk variabel komunikasi dari mulut ke mulut adalah .000. Karena nilainya di bawah .05 maka H0 ditolak. Sumbangan komunikasi dari mulut ke mulut terhadap intensi pepindahan merek adalah sebesar 30.7 persen.

\section{Pengaruh Tipe Kepribadian terhadap Intensi Perpindahan Merek}

Hipotesis kedua pada penelitian ini adalah ada pengaruh tipe kepribadian terhadap intensi perpindahan merek. Dari hasil uji anakova diperoleh hasil seperti tabel di bawah ini:

Hasil Uji Anakova Tipe Kepribadian dan Intensi Perpindahan Merek

Berdasarkan tabel terlihat bahwa angka signifikansi untuk variabel tipe kepribadian adalah .017 , Karena nilainya di bawah .05

\begin{tabular}{|c|c|c|c|}
\hline Tipe kepribadian & M & $S D$ & $N$ \\
\hline Introvert & 46.2571 & 10.49545 & 105 \\
\hline Ekstrovert & 45.9684 & 10.96283 & 158 \\
\hline Total & 46.0837 & 10.75937 & 263 \\
\hline
\end{tabular}

mbangan efektif tipe kepribadian terhadap intensi perpindahan merek adalah sebesar 2.2 persen.

Tabel Deskriptif Tipe Kepribadian

Berdasarkan tabel, rerata intensi perpindahan merek pada tipe kepribadian introvert ( $M=46.2571 ; S D=10.49545)$ lebih tinggi dibandingkan dengan tipe kepribadian ekstrovert $\quad(\mathrm{M}=45.9684 ; \quad \mathrm{SD}=10.96283)$. Oleh karena itu dapat disimpulkan bahwa tipe kepribadian introvert lebih berpengaruh terhadap intensi perpindahan merek dibanding tipe kepribadian ekstrovert.

\section{Pengaruh Komunikasi dari Mulut ke Mulut dan Tipe Kepribadian terhadap Intensi Perpindahan Merek}

\begin{tabular}{lcccccc}
\hline \multicolumn{1}{c}{ Source } & $\begin{array}{c}\text { Type III Sum of } \\
\text { Squares }\end{array}$ & Df & MS & $F$ & $p$ & $\begin{array}{c}\text { Partial Eta } \\
\text { Squared }\end{array}$ \\
\hline Corrected Model & 9313.4049 & 2 & 4656.702 & 57.608 & .000 & .307 \\
Intercept & 307.075 & 1 & 307.075 & 3.799 & .052 & .014 \\
Wom & 9308.143 & 1 & 9308.143 & 115.152 & .000 & .307 \\
Tipekepri & 467.671 & 1 & 467.671 & 5.786 & .017 & .022 \\
Error & 21016.756 & 260 & 80.834 & & & \\
Total & 588864.000 & 263 & & & & \\
Corrected Total & 30330.160 & 262 & & & & \\
\hline a. R Squared $=.307$ (Adjilsted R Squared $=.302$ ) & & & \\
\hline
\end{tabular}


Hipotesis ketiga pada penelitian ini adalah ada pengaruh komunikasi dari mulut ke mulut dan tipe kepribadian terhadap intensi perpindahan merek. Dari hasil uji anakova diperoleh hasil seperti tabel di bawah ini:

Hasil Uji Anakova Komunikasi dari Mulut ke Mulut dan Tipe Kepribadian terhadap Intensi Perpindahan Merek

Pada bagian corrected model, terlihat bahwa angka signifikansinya adalah sebesar .000. Karena nilai signifikansi jauh di bawah .05 maka H0 ditolak. Sumbangan efektif komunikasi dari mulut ke mulut dan tipe kepribadian terhadap intensi perpindahan merek adalah sebesar 30.7 persen.

\section{DISKUSI}

Hasil penelitian menunjukkan bahwa secara bersama-sama komunikasi dari mulut ke mulut dan tipe kepribadian berpengaruh secara signifikan terhadap intensi perpindahan merek. Namun, tipe kepribadian yang paling berpengaruh terhadap intensi perpindahan merek adalah tipe kepribadian introvert dibanding tipe kepribadian ekstrovert.

Komunikasi dari mulut ke mulut merupakan komunikasi informal tentang produk atau jasa dan berbeda dengan komunikasi formal. Karena dalam

\begin{tabular}{|c|c|c|c|c|c|}
\hline Variabel & $\begin{array}{l}\text { Type IIIS Siml } \\
\text { of Syulares }\end{array}$ & If MS & $F$ & p & $\begin{array}{l}\text { Portial Eta } \\
\text { Sgumeded }\end{array}$ \\
\hline Tipe Kepribadian & 467,671 & $1 \quad 467.671$ & 5.786 & .017 & .022 \\
\hline
\end{tabular}

komunikasi informal pengirim tidak berbicara dalam kapasitas seorang profesional atau komunikator komersial, tetapi cenderung sebagai teman. Oleh karena itu komunikasi dari mulut ke mulut cenderung lebih persuasif karena pengirim pesan tidak mempunyai kepentingan sama sekali atas tindakan si penerima setelah itu (Prasetijo \& Ihalauw, 2005). Komunikasi dari mulut ke mulut ditemukan berpengaruh terhadap intensi perpindahan merek pada konsumen. Katz dan Lazarsfeld (1956) menemukan bahwa komunikasi dari mulut ke mulut memainkan peran penting dalam mempengaruhi pelanggan untuk mengganti merek. Telah terbukti bahwa pengaruh komunikasi dari mulut ke mulut terhadap intensi perpindahan merek tujuh kali lebih besar dari pada surat kabar dan majalah. Selain itu, komunikasi dari mulut ke mulut memberi empat kali lebih besar bagi pelanggan untuk beralih merek daripada penjualan dari sales.

Disisi lain, intensi perpindahan merek tidak hanya dipengaruhi oleh komunikasi dari mulut ke mulut melainkan juga kepribadian. hal ini sejalan dengan pernyataan Mangkunegara (2002), bahwa persepsi dan pengambilan keputusan dalam membeli juga dipengaruhi oleh kepribadian konsumen. Feist dan Feist (2010) menyatakan bahwa orang dengan tipe kepribadian introvert memiliki pemahaman yang baik terhadap dunia dalam diri mereka. orang-orang ini akan menerima dunia luar dengan sangat selektif dan dengan pandangan subjektif mereka. Sedangkan orang dengan tipe kepribadian ekstrovert akan lebih mudah untuk dipengaruhi oleh sekelilingnya dibanding oleh kondisinya sendiri.

Hal inilah yang dimanfaatkan oleh X, salah satu merek kosmetik keluaran PT X. 
keberhasilan $\mathrm{X}$ dalam membangun merek tidak bisa dilepaskan dari peran komunitas. Kehadiran komunitas sangat membantu bisnis X. Salah satu komunitas yang digandeng oleh $\mathrm{X}$ adalah Hijabers Community. $\mathrm{X}$ mendorong agar komunitas ini semakin terlihat dengan selalu mendukung segala aktivitas yang mereka lakukan, mulai dari fashion show, launching buku, dan apapun selalu didukung (Supriadi, 2014).

Supranto dan Limakrisna (2007) menyatakan bahwa komunitas dapat mempengaruhi konsep diri seseorang. Bagi konsumen yang menilai bahwa merek $\mathrm{X}$ dapat menguatkan konsep dirinya maka akan menimbulkan loyalitas merek. Loyalitas merek bisa timbul ketika konsumen percaya merek merefleksikan atau menguatkan konsep dirinya.

Namun hal ini kurang berpengaruh bagi orang dengan tipe kepribadian introvert. Karena mereka memiliki pemahaman yang baik terhadap dunia dalam diri mereka. orang-orang ini akan menerima dunia luar dengan sangat selektif dan dengan pandangan subjektif mereka (Feist \& Feist, 2010), dan mereka lebih mengutamakan kegunaan produk untuk dirinya (Prasetijo \& Ihalauw, 2005). Ketika merek tidak sesuai dengan harapan dan menimbulkan ketidakpuasan maka respon mereka adalah beralih merek (Supranto \& Limakrisna, 2007). Smith (2012) menemukan bahwa tidak ada pengaruh tipe kepribadian introvert terhadap kecendrungan untuk setia terhadap suatu merek, artinya orang dengan tipe kepribadian introvert juga cenderung memiliki intensi untuk berpindah merek.
Berdasarkan hal tersebut, dapat disimpulkan bahwa komunikasi dari mulut ke mulut dan tipe kepribadian secara bersama-sama berpengaruh terhadap intensi perpindahan merek pada konsumen. Komunikasi dari mulut ke mulut yang dilakukan oleh orang yang dipercaya karena tidak memiliki motif pribadi disertai dengan kepribadian yang lebih mengutamakan kegunaan suatu produk dibanding diterima dilingkungan sosialnya secara bersama-sama dapat mempengaruhi intensi berpindah merek pada konsumen.

\section{Kesimpulan}

1. Terdapat pengaruh yang positif dan signifikan antara komunikasi dari mulut ke mulut terhadap intensi perpindahan merek. Artinya semakin sering dan positif komunikasi dari mulut ke mulut yang diberikan, maka akan semakin tinggi pula intensi perpindahan merek pada konsumen.

2. Terdapat pengaruh yang signifikan antara tipe kepribadian terhadap intensi perpindahan merek, dimana tipe kepribadian introvert lebih besar pengaruhnya terhadap intensi perpindahan merek dibanding tipe kepribadian ekstrovert.

3. Terdapat pengaruh yang signifikan antara komunikasi dari mulut ke mulut dan tipe kepribadian terhadap intensi perpindahan merek.

4. Koefisien determinasi (R) dari komunikasi dari mulut ke mulut dan tipe kepribadian mampu memberikan kontribusi terhadap intensi perpindahan merek sebesar $30.7 \%$ dan sisanya sebesar $69.3 \% \%$ dijelaskan oleh variabel bebas lainnya yang belum diteliti. 


\section{Saran}

1. Berdasarkan nilai koefisien determinasi untuk komunikasi dari mulut ke mulut dan tipe kepribadian yang hanya memiliki nilai sebesar $30.7 \%$, maka masih terdapat variabel lain yang mempengaruhi intensi perpindahan merek yang dapat digunakan dalam penelitian lanjutan seperti usia, variety seeking, iklan, promosi penjualan, kualitas, harga, dll.

2. Hasil penelitian ini dapat menjadi tambahan rujukan bagi penelitian selanjutnya serta sebagai pertimbangan bagi perusahaan kosmetik lainnya.

3. Konsumen yang sering terlibat dalam komunikasi dari mulut ke mulut memiliki intensi lebih besar untuk berpindah ke merek lainnya, hal ini dapat dimanfaatkan oleh perusahaan kosmetik yang ingin menarik konsumen baru dengan cara melakukan pemasaran kepada orang yang paling berpengaruh dalam satu komunitas, mengetahui tentang perkembangan produk terbaru, serta senang berbagi cerita kepada rekan atau kerabatnya mengenai hal - hal yang mereka ketahui. Sehingga semakin banyak orang yang mengetahui informasi mengenai merek kosmetik dan menyebarluaskan informasi tersebut kepada konsumen lain.

4. Perusahaan yang ingin mengurangi intensi perpindahan merek pada konsumen, bisa memberikan tes kepribadian disertai survei mengenai faktor-faktor apa yang bisa membuat konsumen beralih dan bertahan menggunakan produk. Perusahaan bisa mengumumkan tes dan survei ini melalui website, media cetak, dan iklan televisi. Hasilnya perusahaan bisa mengetahui faktor-faktor apa yang bisa membuat tipe kepribadian introvert bertahan dan faktorfaktor apa yang bisa membuat tipe kepribadian ekstrovert beralih menggunakan produk, lalu menerapkannya dalam strategi marketing perusahaan.

\section{DAFTAR PUSTAKA}

Ananda, H.R. (2015). Pengaruh atribut produk, harga dan promosi terhadap perilaku brand switching pelanggan ke Telkomsel Sosialita. Jurnal Universitas Brawijaya, 1(2), 1-22.

Ajzen, I., \& Fishbein, M. S. (1975). Beliefs, Attitude, Intention, and Behavior. Massachussets: Addison Wesley Publishing Company.

Boyd, W., Walker, O., \& Claude, J. (2000). Manajemen pemasaran : Suatu pendekatan strategis dengan orientasi global. Jakarta: Erlangga.

Darmawati, D., Subekti, B., Murni S., \& Sumarsono. (2007). Analisis pengaruh kebudayaan, sosial, kepribadian dan psikologis terhadap keputusan pembelian Shar'e, Journal Performance, 6(1),16-32.

Destarania. (25 Januari 2012). Fenomena "brand switching" konsumen Indonesia. Diunduh dari http://www.kompasiana.com/destarani a/fenomena-brand-switchingkonsumenindonesia 550d8459a33311081c2e3c4 d. Diakses pada tanggal 04 Juli 2017. 
Emelia, S. (2013). Pengaruh atribut produk, kepuasan, dan variety seeking terhadap brand switching konsumen rinso ke merek lain di kota Padang. Jurnal Manajemen, 2(2), 1-13.

Feist, J., \& Feist, G. J. (2010). Teori kepribadian. (10th ed.). Jakarta : Salemba Humanika.

Femina. (11 April 2016). 5 produk kosmetik lokal favorit. Diunduh dari http://www.femina.co.id/beautytrend/5-produk-kosmetik-lokal-favorit. Diakses pada tanggal 04 Juli 2017.

Harrison-Walker, L. J. (2001). The measurement of word-of-mouth communication and an investigation of service quality and customer commitment as potential antecedents. Journal of Service Research, 4(1), 60 75.

Hoyer, W.D., \& Macinnis, D.J. (2008). Consumer behavior (5th ed.). USA: Cengage Learning.

Irawan, H. (2016). 3 rules for success in building top brands. Jakarta : Penerbit Publishing One.

Katz, E., \& Lazarsfeld, P.F. (1956). Personal influence : The part played by people in the flow of mass communication. New York : The Free Press.

Khasanah, A.U., \& Kuswadi, R. (2013). Analisis faktor-faktor yang mempengaruhi perpindahan merek pada produk smartphone. Jurnal Manajemen dan Bisnis, 17(2),123-131.
Mangkunegara, A. P. (2002). Perilaku Konsumen (Edisi revisi). Bandung : PT. Refika Aditama.

Mangkunegara, A.P. (2009). Perilaku konsumen. Bandung: PT Refika Aditama.

Mantasari, A.D., Rahmawati, I., Silviandari, I.A. (2013). Perilaku brand switching (perubahan merek) pada telepon seluler yang dipengaruhi oleh reference group (kelompok acuan) (studi pada mahasiswa psikologi Universitas Brawijaya Malang). Jurnal Universitas Brawijaya Malang.

Mowen, J.C., \& Minor, M. (2002). Perilaku konsumen (Edisi kelima jilid 2). Jakarta: Erlangga.

Myers, I.B., Kirby, L.K., Myers, K.D. (2000). Introduction to type: A guide to understanding your results on the MBTI instrument. USA: CPP Incorporated.

Nandifa, N. (18 Agustus 2016). Memilih kosmetik bagi wanita. Diunduh dari http://cottonheavenshop.com/memilihkosmetik-untuk-wanita/. Diakses pada tanggal 04 Juli 2017.

Nugraheni, A. (7 Juni 2016). Rimba kosmetik di era digital. Diunduh dari http://print.kompas.com/baca/2016/06/ 07/Rimba-Kosmetik-di-Era-Digital. Diakses pada tanggal 04 Juli 2017.

Nuraeni. (2014). Analisis faktor-faktor yang mempengaruhi perilaku brand switching pada kartu prabayar XL 
(studi pada konsumen Pandumedia Reload Service Singosari-Malang). Jurnal sketsa Bisnis, 1(1), 1-15.

Olsen, S.O., Tudoran, A.A., Honkanen, P., \& Verplanken, B. (2016). Differences and similarities between impulse buying and variety seeking : A personality based persfective. Psychology and Marketing, 33(1), 3647.

Peter, J. P., \& Olson, J. (2000). Perilaku konsumen dan strategi pemasaran (edisi 4 jilid 2). Newyork: McGrawHill.

Prasetijo, R., \& Ihalauw, J.J.O.I. (2005). Perilaku konsumen. Yogyakarta : Penerbit Andi.

Pratiwi, W.M. (9 Februari 2017). Studi Pemasaran Produk Kosmetik 2017. Diunduh dari https://id.linkedin.com/pulse/studipemasaran-produk-kosmetik-2017winda-mizwar-pratiwi-1. Diakses pada tanggal 04 Juli 2017.

Radamuri, G.Y.D., Farida, N., \& Dewi, R. S. (2013). Pengaruh citra merek, word of mouth dan iklan terhadap keputusan perpindahan merek. Jurnal Ilmu Administrasi Bisnis, 2(3), 380-386.

Ramshita, A.P., \& Manikandan, K. (2013). Personality and customer brand switching. Guru Journal of Behavioral and Social Sciences, 1(3), 152-160.
Sekaran, U. (2006). Metodologi penelitian untuk bisnis (edisi keempat). Jakarta: Salemba Empat.

Sudarsono. (1993). Kamus filsafat dan psikologi. Jakarta: Rineka Cipta.

Supranto, J., \& Limakrisna, N. (2007). Perilaku konsumen dan strategi pemasaran untuk memenangkan persaingan bisnis. Jakarta : Mitra Wacana Media.

Supriadi, C. (8 Maret 2014). Wardah, lari kencang bersama komunitas. Diunduh dari

http://www.marketing.co.id/wardahlari-kencang-bersama-komunitas/. Diakses pada tanggal 04 Juli 2017.

Suryani, T. (2008). Perilaku konsumen : Implikasi pada strategi pemasaran. Yogyakarta: Graha Ilmu.

Suryabrata, S. (2008). Psikologi kepribadian. Jakarta: PT Raja Grafindo Persada.

Tilaar, M. (2009). Kecantikan perempuan timur. Magelang: Indonesia Tera.

Undari, S.H. (2016). Perbedaan perilaku konsumtif siswa SMK Karya Rini ditinjau dari tipe kepribadian introvert dan ekstrovert. Jurnal Bimbingan dan Konseling, 5(7), 28-37.

Venny, J. (2010). Analisis faktor-faktor yang mempengaruhi brand switching ke Blackberry. (Tesis). Gadjah Mada University, Yogyakarta. 